\title{
PUBLIC DIPLOMACY AS A TOOL OF SHAPING THE PERCEPTION OF UKRAINE IN THE WEST AMID THE AGGRAVATION OF RELATIONS WITH RUSSIA
}

\section{ПУБЛІЧНА ДИПЛОМАТІЯ ЯК ІНСТРУМЕНТ ФОРМУВАННЯ СПРИЙНЯТТЯ УКРАЇНИ НА ЗАХОДІ В УМОВАХ ЗАГОСТРЕННЯ ВІДНОСИН 3 РОСІЕЮ}

\section{ПУБЛИЧНАЯ ДИПЛОМАТИЯ КАК ИНСТРУМЕНТ ФОРМИРОВАНИЯ ВОСПРИЯТИЯ УКРАИНЫ НА ЗАПАДЕ В УСЛОВИЯХ ОБОСТРЕНИЕ ОТНОШЕНИЙ С РОССИЕЙ}

\section{Pipchenko N.}

Doctor of Political Sciences, Associate Professor, Associate Professor at the Department of International Information, Institute of International Relations, Taras Shevchenko National University of Kyiv. E-mail: nataliyapo@gmail.com.

\section{Dovbenko M.}

Master of International Communications, Institute of International Relations, Taras Shevchenko National University of Kyiv. E-mail: mariiadovbenko@gmail.com.

\section{Піпченко Н. О.}

Доктор політичних наук, доцент, доцент кафедри міжнародної інформації Інституту міжнародних відносин Київського національного університету імені Тараса Шевченка. Електронна пошта: nataliyapo@gmail.com.

\section{Довбенко М. I.}

Магістр міжнародних комунікацій Інституту міжнародних відносин Київського національного університету імені Тараса Шевченка. Електронна пошта: mariiadovbenko@gmail.com.

Пипченко Н. А.

Доктор политических наук, доцент, доцент кафедры международной информации Института международных отношений Киевского национального университета имени Тараса Шевченко. Электронная почта: nataliyapo@gmail.com.

\section{Довбенко М. И.}

Магистр международных коммуникаций Института международных отношений Киевского национального университета имени Тараса Шевченко. Электронная почта: mariiadovbenko@gmail.com.

Abstract. The article is devoted to the analysis of Ukraine's public diplomacy in terms of aggravation of relations with Russia. Public diplomacy is researched as an instrument for shaping the perception of Ukraine in the West that is exposed to constant threats of information influence by the Russian Federation.

The paper analyses the role of public diplomacy in shaping the favorable image of the state in the mass consciousness and ensuring national interests in the international arena. The peculiarities of the development of public diplomacy of Ukraine at the institutional and practical levels being intensified since 2014 after the beginning of Russian aggression against Ukraine, are determined. Conceptual documents and specially created institutions for shaping a positive perception of Ukraine abroad and disrupting negative influence of Russian propaganda are examined. As a result, the main directions of Ukraine's public diplomacy are the development ties with the public and media; realization of image, cultural and informational projects abroad; cooperation of governmental bodies for supporting foreignpolicy interests. 
Through the content analysis of the Western media space on the coverage of Ukraine and the expert assessment of public diplomacy of Ukraine, the peculiarities of the influence of Ukrainian public diplomacy on shaping its perception in the West were identified and a set of recommendations was developed to improve Ukraine's perceptions in the face of aggravation of relations with Russia. These include developing West and Russian directions of public diplomacy, intensifying media coverage of Ukraine, changing narratives about Ukraine as well as engaging civil activists and artists for promotion the national interests abroad.

Key words: Ukraine, Russia, the West, public diplomacy, information aggression, propaganda, perception.

Анотація. Стаття присвячена аналізу публічної дипломатії України в умовах загострення відносин з Росією. Публічна дипломатія розглядається як інструмент формування сприйняття Украйни на Заході, який перебуває під постійними загрозами інформачійного впливу з боку Російської Федерачіӥ.

У роботі проаналізовано роль публічної дипломатії у формуванні сприятливого образу держави в масовій свідомості $i$ забезпечення начіональних інтересів на міжнародній арені. Визначено особливості становлення публічної дипломатії України на інституиійному та практичному рівнях, що активно розвиваються з 2014 року після початку російської агресії проти Украӥни. Розглянуто концептуальні документи та спечіально створені інституції, покликані формувати позитивне сприйняття України за кордоном та протидіяти негативному впливу російської пропаганди. За допомогою контент-аналізу західного медіапростору щодо висвітлення України та експертної очінки публічної дипломатії України встановлено особливості впливу публічної дипломатії України на формування ї сприйняття на Заході та розроблено рекомендації з метою покращення сприйняття держави в умовах загострення відносин з Росією. До рекомендачій можна віднести розвиток західного і російського напрямів публічної дипломатії, посилення медіависвітлення та зміну наративів про Україну, а також залучення громадських активістів $i$ артистів до просування начіональних інтересів держави за кордоном.

Ключові слова: Украӥна, Росія, Захід, публічна дипломатія, інформачійна агресія, пропаганда, сприйняття.

Аннотация. Статья посвящена анализу публичной дипломатии Украины в условиях обострения отношений с Россией. Публичная дипломатия рассматривается как инструмент формирования восприятия Украины на Западе, который находится под постоянными угрозами информачионного влияния со стороны Российской Федерачии.

В работе проанализирована роль публичной дипломатии в формировании благоприятного образа государства в массовом сознании и обеспечении национальных интересов на международной арене. Определены особенности становления публичной дипломатии Украины на институчиональном $u$ практическом уровне, что активизировалось с 2014 года после начала российской агрессии против Украины. Рассмотрены кониептуальные документы и специально созданные институты, призванные формировать позитивное восприятие Украины за рубежсом $и$ противодействовать негативному влиянию российской пропаганды. C помощью контент-анализа западного медиапространства $и$ экспертной оценки публичной дипломатии Украинь обозначень особенности влияния публичной дипломатии Украины на формирование ее восприятия на Западе и разработаны рекомендачии с целью улучшения восприятия страны в условиях обострения отношений с Россией. K рекомендачиям можно отнести развитие западного и российского направлений публичной дипломатии, усиление медиаосвещения и изменение нарративов об Украине, 
Actual problems of international relations. Release 138. 2019

a также привлечение общественных активистов $и$ артистов $\kappa$ продвижению национальных интересов государства за границей.

Ключевые слова: Украина, Россия, Запад, публичная дипломатия, информачионная агрессия, пропаганда, восприятие.

The current problem. The new hybrid world order is drastically transforming the relations among the states highlighting the information dimension of existence. Thus, information and communication in the forms of public diplomacy, strategic communications or propaganda are becoming the main asset and weapon in the hands of the states. The defining role of communication tools in the international arena became increasingly evident since the launch of Russian information aggression in 2014 which operationally directed against Ukraine but strategically against the whole Western world. Ukraine found itself in the spotlight of Russian propaganda aimed at undermining its territorial integrity, independence and image of the state in the international arena. Such situation requires from Ukraine to take efficient communication countermeasures to restore its international reputation and to curb the negative impact of Russian information influence.

The aim of the article is to analyse the use of public diplomacy by Ukraine in shaping the perception of the country abroad amid expansive propaganda of the Russian Federation and to develop a set of recommendations for strengthening efforts of Ukraine to eliminate the negative impact of Russian information aggression and to improve its perception in the Western world.

Analysis of the latest publications. The communication as an integral part of the state policy has been researched since the beginning of the XX century. The close attention to this issue was paid by J. Ellul [Ellul, 1973: 61], Cull N., E. Gullion [Cull, 2006], J. Nye [Nye, 2008: 97], L. Lapham, M. McLuhan [McLuhan, Lapham, 1994: 264]. The shift to focus on phenomenon of public diplomacy as a foreign communication technology was made due to circumstances of political agenda. The term 'propaganda' prevailed in the political narrative since World War II with extremely negative connotation, thus, required a substitute. In 1965 an American diplomat E. Gullion coined the term 'public diplomacy' defining it as 'the influence of public attitudes on the formation and execution of foreign policies. It encompasses dimensions of international relations beyond traditional diplomacy . . . [including] the cultivation by governments of public opinion in other countries; the interaction of private groups and interests in one country with those of another . . . (and) the transnational flow of information and ideas' [5]. Subsequently, the phenomenon of public diplomacy became a household name in the U.S. and the concept was emulated by other Western countries. The public diplomacy was used as a tool of 'soft power', concept elaborated by J. Nye [Nye, Owen, 1996: 21]. Since the phenomenon of public diplomacy is relatively modern, it is being actively researched by scholars nowadays from different angles as an instrument of interaction [Zaharna, 2010: 233], shaping public opinion [Ross, 2003: 25] or as an integral part of strategic communications [Department of Defence, 2009].

Among the Ukrainian scholars, the significant contribution to the study of public diplomacy was made by O. Zernetska [Zernetska, 1999: 177], O. Kondratenko [Kondratenko, 2017: 196], I. Khyzhnyak [Khyzhnyak, 2018: 217], O. Kuchmii [Kuchmii, 2016: 157], E. Makarenko [Makarenko, 2016: 55], E. Tykhomyrova [Tykhomyrova, 2004: 114] and others which focus their research on the role of public diplomacy in the system of foreign-policy communication.

The important research results. The strengthening of Russian information and military aggression against Ukraine in 2014 put into question the position of our country in the international arena. The policy of Ukraine was hardly articulated to international community due to the lack of consistent and pro-active communications of the state. Though the official statements of Ukraine were communicated by default, they were perceived poorly 
and dominated by Russian assertive communications. As a result, the public diplomacy surfaced as an efficient tool and strategy on the agenda of Ukrainian Government.

The development of Ukraine's public diplomacy was enshrined within legal framework. The key strategic papers in this regard are the Doctrine of Information Security of Ukraine approved in 2016 and the Concept of Ukraine's popularization in the world and promotion of Ukraine's interests in the global information space approved in 2016 [1-3]. The development of public diplomacy of Ukraine is determined as a priority of state information policy directed to shaping positive international image [1]. The set of communication and information activities for the promotion of Ukraine's image in the world is outlined in the Concept of Ukraine's popularization in the world and promotion of Ukraine's interests in the global information space [2]. In order to insure the practical realization of public diplomacy the Plan of Action on Implementing Concept of Popularization of Ukraine in the World was developed and came into force in 2017. It includes the following activities [3]:

- Developing unified standard of elements for the promotion of Ukraine, in other words- brand development;

- Conducting comprehensive campaigns of popularization of Ukraine in certain regions of the world;

- Increasing the level of Ukraine's presence in international events and on information platforms in the academic, cultural and public domains;

- Fulfilling projects of cultural diplomacy and strategies for popularizing Ukraine's potential in the world;

- Strengthening tourist potential of Ukraine;

- Distributing information about export opportunities of Ukraine.

The institutional role in the realization of the above public diplomacy activities belongs to different state bodies, namely the Ministry of Information Policy of Ukraine, the Ministry of Foreign Affairs of Ukraine, the Ministry of Culture of Ukraine, the Ministry of Education and Science of Ukraine, the Ministry of Economic Development and Trade of Ukraine. Such intergovernmental approach in public diplomacy requires efficient coordination mechanisms. For this purpose, the Interdepartmental Commission on Ukraine's Popularization in the World was established, coordinating the efforts of the above ministries and involving nongovernmental representatives.

The specific institutional role in public diplomacy belongs to the Ministry of Foreign Affairs of Ukraine. The structural unit known as the Division of Public Diplomacy was set up in the Ministry to prioritize public diplomacy in the policy of foreign communications of Ukraine. The scope of work of the Division of Public Diplomacy includes [Kuleba, 2015]:

- Developing relations with the public, public associations and media of other countries and Ukraine;

- Realizing image, cultural and informational projects of Ukraine abroad;

- Coordinating measures of other governmental bodies in these spheres.

The specialized institution known as the Ukrainian Institute is established within the Ministry of Foreign Affairs to ensure cultural promotion of state abroad. The format of this institution is based on the international prototypes such as the British Council, the GoetheInstitut and the French Institute. The central bureau of the Ukrainian Institute is to carry out planning and strategic coordination of the cultural and image presentation of Ukraine in the world while the branches of the Ukrainian Institute in the most prioritized for Ukraine countries are to take activities in such public events. The central bureau of the Ukrainian Institute has been fully operating since the end of 2018 with the ambition to realize a number of activities in 2019 planned in its strategy of work [Vyshnytska, 2018].

The newly established Ministry of Information Policy of Ukraine in 2014 aimed at countering Russian information influence hit the track of public diplomacy with the special competence on foreign broadcasting. The Ministry fully supervises the two state foreign broadcasting channels, the international broadcasting multimedia platform UA/TV and 
national information agency Ukrinform. Besides this specific competence, the Ministry of Information Policy takes a number of information activities to popularize Ukraine in the world. The other sectoral ministries involved in public diplomacy have specific tasks assigned to them.

Under increasing information impact of the Russian Federation legal and institutional development of public diplomacy of Ukraine takes place concurrently with the practical implementation of public diplomacy activities, including national branding development, international broadcasting, movies promotion, hosting of international events and conducting strategic communication campaigns.

Ukraine presented its brand platform 'Ukraine NOW' which became a significant step in nation brand building. The unified visual and vision framework of presenting our country is to strengthen its identity in the perception of the international community. All the Ukrainian governmental bodies and institutions are obliged to use the unified brand platform in the communications while all non-governmental bodies and Ukrainian citizens are welcome to promote it by all possible means in accordance with developed brand book [Bidenko, 2018].

Ukraine initiated the launch of international broadcasting system in order to counter expansive propaganda by Russia Today. Primarily, the private initiative of $1+1$ media holding called Ukraine Today served for this purpose but subsequently the state took a leading role in developing international broadcasting in the form of public multimedia platform UA/TV. Multimedia platform UA/TV is available via satellite in Europe, North America and Asia, via cable operators in 15 countries of the world, via the Internet as YouTube channel and website. The overview of Internet traffic of platform demonstrates extremely low number of total visits per month in comparison to Russia Today with $89 \%$ share of visits from Ukraine (pic.1).

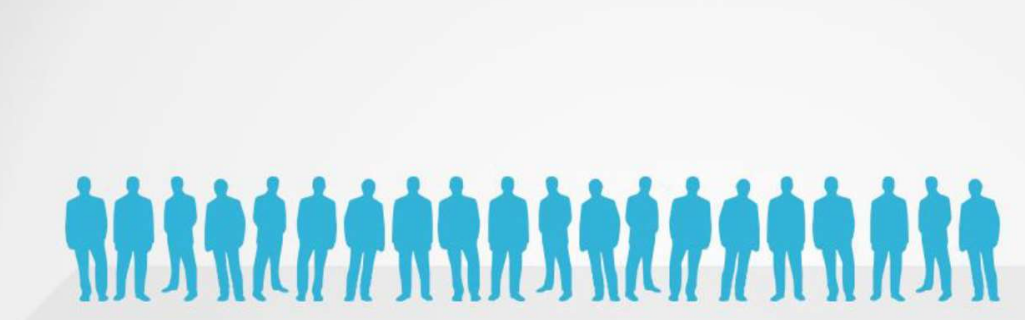

162280000

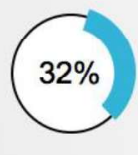

VISITS FROM RUSSIA
RUSSIA TODAY

\section{UA/TV}

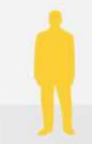

268230

$89 \%$

VISITS FROM UKRAINE

Pic. 1. Website traffic per month of international broadcasting platforms of Russia (Russia Today) and Ukraine (UA/TV)

Source: prepared by authors based on data from website SimilarWeb, dated of September 2018

The analysis of content of UA/TV multimedia platform revealed the lack of a clear understanding of the audience to which the content is directed, the way of coverage resembles the Soviet style including usually only comments by officials, the selection of news is chaotic and often contains information not interesting to foreign audience, the presence of political bias in the coverage, unclear visual newsfeed (several running lines of news in different languages which are often not related at all) [23].

Besides public international broadcasting a number of initiatives for civil society have been successfully established and operated, including Hromadske International, Ukrainian 
Crisis Media Centre, StopFake, Euromaidan Press, Magazine 'The Ukrainian: Life and Culture'. Though the exposure of the above platforms is not expansive, their content is relevant and targeted to key audiences.

Since 2014 Ukraine has given a fresh impulse to its movie industry. The number of movies produced by Ukraine increased, they were more actively presented to international audience and the Ukrainian film festivals were organized internationally. In this regard, the following movies should be highlighted: 'The Tribe' (the first Ukrainian movie in the U.S. box office and the one got 3 Cannes Award), animation movie 'The Stolen Princess' (shown in more than 40 countries worldwide) and 'The Cyborgs' (presented with the support of the Ministry of Foreign Affairs of Ukraine in a number of world renowned cities).

The other public diplomacy activities worth mentioning are international events hosted by Ukraine during the recent years. In 2017 Ukraine organized European Song Contest at a very high level according to assessment by the European organizers. The hosting of Eurovision strongly contributed to improving perception of Ukraine by foreigners. According to results of survey prepared by JfK Ukraine, $47 \%$ of respondents stressed that Ukraine surpassed their expectations, $51 \%$ of the guests said that Ukraine fully met their expectations and $92 \%$ of respondents expressed their desire to visit Ukraine again [24]. In 2018 Ukraine also hosted UEFA Champions League Final very professionally. The number of cultural and entertainment events were organized for tourists in Kyiv though no special communication campaigns or newsbreak were prepared by the Ministry of Foreign Affairs of Ukraine or the Ministry of Information Policy of Ukraine.

The public diplomacy activities of Ukraine within the period of 2014-2018 includes different communication campaigns launched by the governmental bodies together with civil society organizations. The campaign \#MyUkraineIs is one of the most prominent examples. The idea of the campaign was to present Ukraine as a diamond cut by dignity, freedom and creativity of Ukrainian people and was realized through modern interactive landing page, campaign in social media and creative hand-outs [22].

The other communication campaign \#LetMyPeopleGo was dedicated to political agenda - liberating Ukrainian prisoners of war and was presented through the campaign in social media, national initiative of creating postcards etc. The Ministry of Foreign Affairs of Ukraine also launched campaign to promote the correct use of the Ukrainian cities' titles (\#KyivNotKiev) by international media and airports in order to eliminate Russian based transliteration [Dovbenko, 2018].

For the first time a huge long-term public diplomacy project was conducted abroad The Year of Ukrainian Language in Germany which was dedicated to the 25th anniversary of establishment of diplomatic relations between Ukraine and Germany. As a part of this project the Embassy of Ukraine in Germany launched creative campaign in social media called 'Proverbs'. The idea of campaign was to present Ukrainian proverbs in the entertaining animated format and to link them with German analogues, thus, contributing building a bridge between two cultures [25]. The communication campaigns mentioned were actively distributed by Ukrainian side, both at the governmental level and by Ukrainian citizens but there was no outreach of international media.

Through the content analysis of the Western media space on the coverage of Ukraine and the expert assessment of public diplomacy of Ukraine, the peculiarities of the influence of Ukrainian public diplomacy on shaping its perception in the West were identified. In particular, the analysis of international media on the coverage of Ukraine demonstrated that the attention of international outlets to Ukraine was extremely high in 2014 and has been decreasing subsequently (pic.2). 


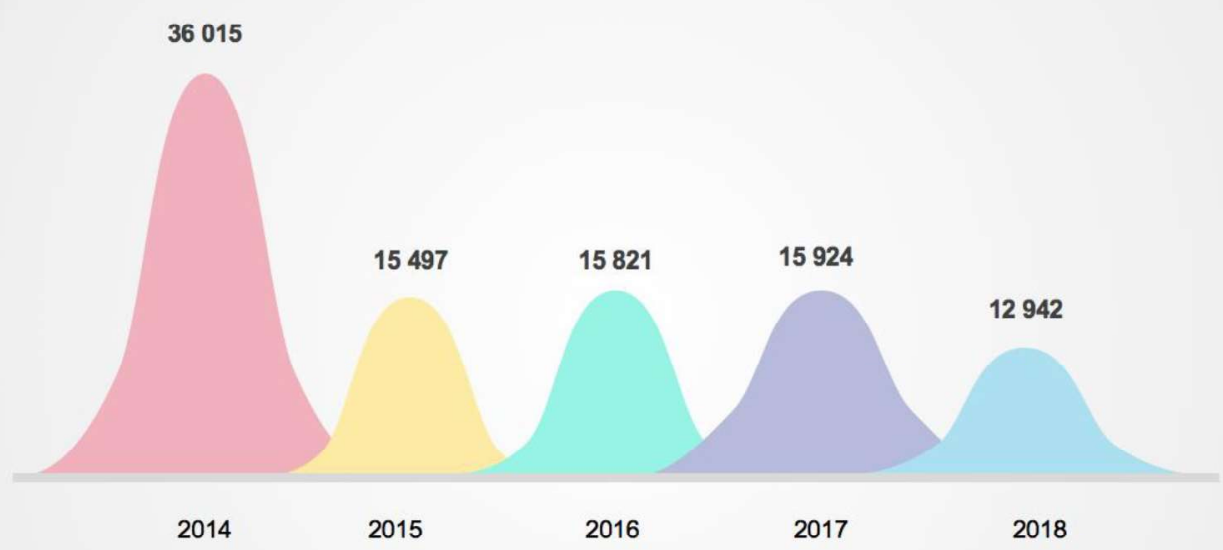

Pic. 2. Dynamics of mentioning Ukraine in the Western media, 2014-2018 Source: prepared by authors based on data from programme Media Cloud

Such close attention of the Western media to Ukraine in 2014 results from a number of newsbreaks about Ukraine in this period. The Western media outlets actively covered shooting down Malaysia Airlines Boeing, Russian annexation of Crimea and intervention of the Russian Federation in Eastern Ukraine. The other injects about Ukraine in the following years included Minsk agreements on the truce in Eastern Ukraine, Manafort scandal disclosing, among others, his connections with former Ukrainian president V. Yanukovych, cyberattack 'Petya' directed against Ukraine and other countries, assassination of Russian journalist A. Babchenko in Ukraine, introduction of martial law in Ukraine (pic. 3).

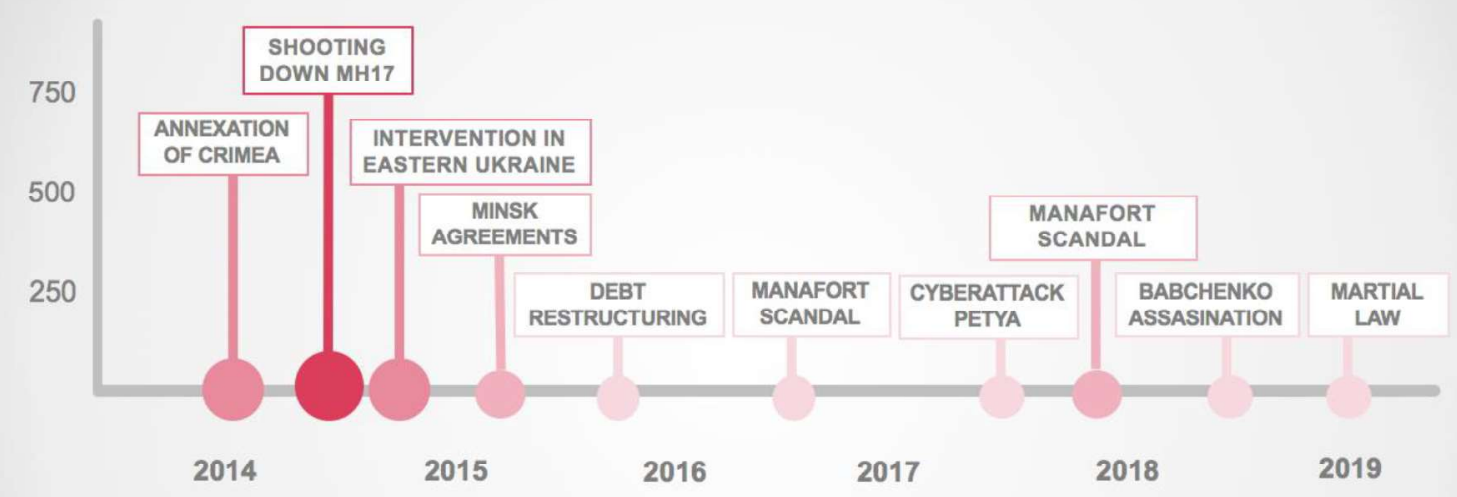

Pic. 3. Map of newsbreaks about Ukraine in the Western media, 2014-2018 Source: prepared by authors based on data from programme Media Cloud

The analysis of top topics related to Ukraine demonstrated that Ukraine was usually covered in relation to war (29 357 media pieces) and corruption (5 914 media pieces). The other topics such as reforms, investments, culture, sport and music are covered not so actively but still the total mentioning amounted to 13792 media pieces. The narrative shaped in the Western media is outlined in the diagram (pic. 4). 


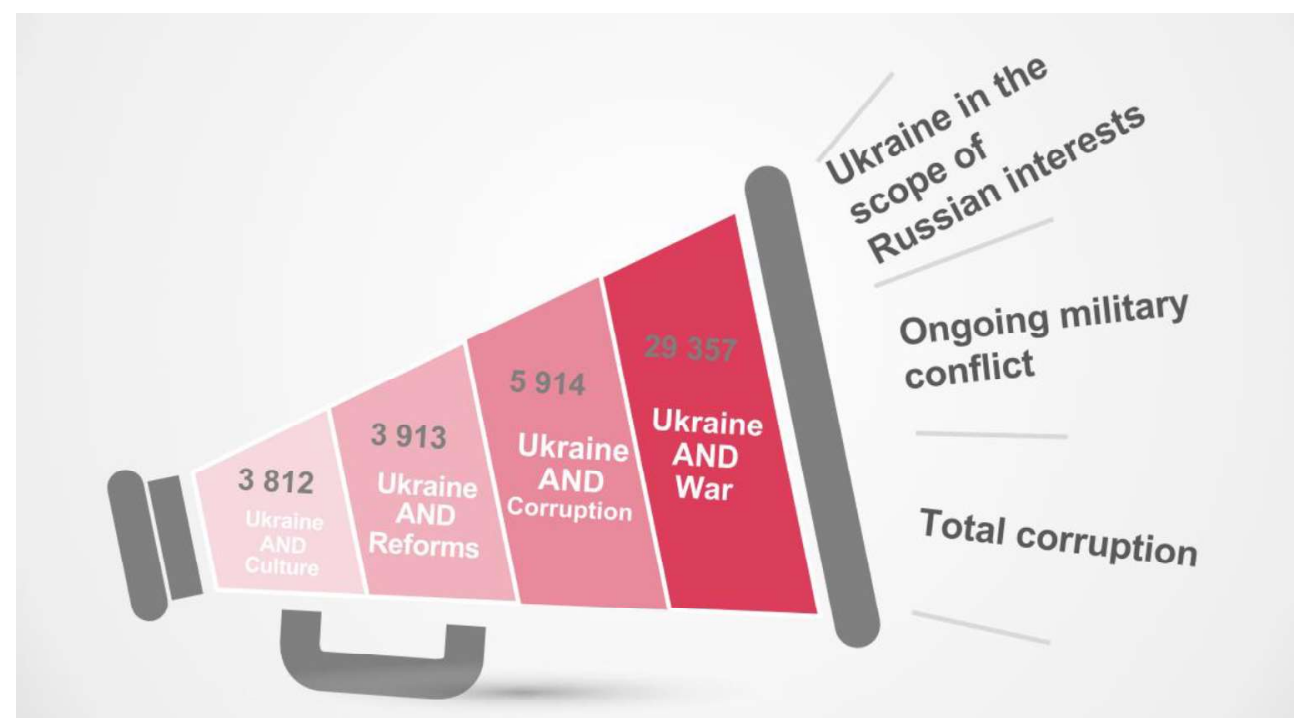

Pic. 4. Narratives about Ukraine in the Western media, 2014-2018 Source: prepared by authors based on data from programme Media Cloud

The coverage of Ukraine in the Western media in 2014-2018 concerned mostly war in the country caused by Russian aggression and some other events which had international dimension. The information about positive changes in Ukraine and its cultural assets were in the peripheral attention of the Western media.

The assessment of public diplomacy of Ukraine by Ukrainian and international experts outlined the current state of public diplomacy and the vision of its improving for shaping positive perception of Ukraine in the West.

The efficiency of public diplomacy of Ukraine is assessed slightly above middle value. There is a full convergence in the assessment by Ukrainian and international experts of the efficiency of public diplomacy in the part of improving the perception of Ukraine and in the part of countering Russian propaganda which amounts to 2.8 points from 5 (pic. 5).

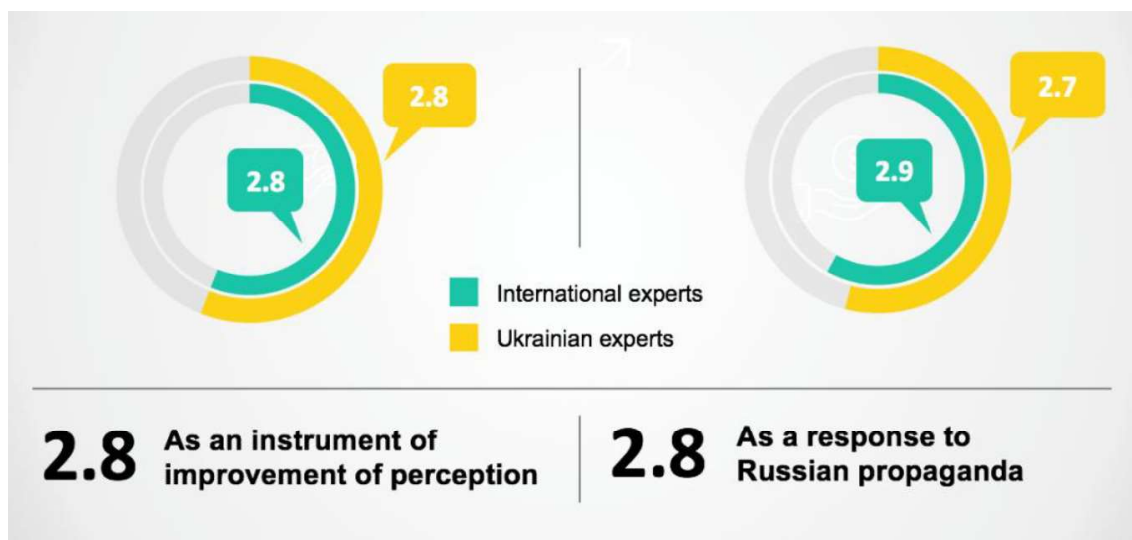

Pic. 5. Assessment of the efficiency of public diplomacy of Ukraine

Source: prepared by authors based on the results of the conducted survey under 5-points scale among Ukrainian and international experts

It should be noted that $85 \%$ Ukrainian and $80 \%$ international experts believe that for the improvement of perception of Ukraine in the West a specific communication strategy towards strategic countries should be developed by the Ministry of Foreign Policy of Ukraine. Most experts consider that Ukraine should work within public diplomacy in the Russian direction as well (72\% Ukrainian experts and 94\% international experts). According to assessment of 
experts, the most positive impact on the perception of Ukraine belongs to the strengthening of civil society (international experts) and conducting of reforms (Ukrainian experts) while the most negative impact belongs to corruption.

Experts determined the key measures and topics of public diplomacy of Ukraine, the key groups of target audience to which they should be directed and the most influential subjects who should direct them. The key target audience should be media and journalists (3.8 and 4.2 points out of 5 by Ukrainian and international experts accordingly), followed by political establishment (3.6 and 3.8 points accordingly) and international organizations (3.4 and 3.9 points accordingly). The main public diplomacy measures should include publications about Ukraine in top world media (4.0 and 4.1 points by Ukrainian and international experts accordingly), organization of cultural events (4.0 and 3.6 points accordingly) and participation in the international events ( 3.8 and 4.1 points accordingly). The above events should primarily cover the topics of conducting reforms ( 3.9 and 4.0 points by Ukrainian and international experts accordingly) and fighting corruption (3.8 and 4.1 points accordingly). The public diplomacy measures should be taken by the President and by civil activists and artists as they have the strongest influence (4.1 points for President by Ukrainian and international experts, 3.3 and 3.9 points for activists and artists by Ukrainian and international experts accordingly) in the change of perception of Ukraine.

The recommendations from experts for improving public diplomacy of Ukraine are as follows:

- Conducting efficient reforms ('Focus on domestic scene, making substantive progress in the reform agenda', Advisor to Government Communication Service, UK);

- Developing comprehensive public diplomacy strategy ('Act strategically and create institutions in charge of public diplomacy', Permanent representative of Ukraine to Council of Europe);

-Ensuring 'one voice' communication ('Make synergy in work of MFA, Ukrainian Institute, embassies and civil society initiatives', Head of Programme sector of Ukrainian Institute; 'Unified public statements by diplomats, civil servants', Head of Sector of Information Security of the Secretariat of National Security and Defense Council of Ukraine);

- Promoting information about Ukraine to international media ('Impartial and professional coverage of events about Ukraine', Head of Art Programme of British Council in Ukraine);

- Improving content about Ukraine ('The messages content to be modernized and made as practical as possible', Head of Cultural Sector of EU delegation to Ukraine);

- Building dialogue ('To look for commonalities, build bridges and develop dialogue', Consul of Consulate General of Ukraine in Munich; 'Ukraine should become an integral part of global discussions', Head of Committee on Foreign Affairs of Verkhovna Rada).

Conclusions. In terms of expansive information aggression of the Russian Federation undermining Ukrainian existence, our country had to take resilient countermeasures to defend its national interests and to restore its stability and reputation in the international arena. Taking into account democratic principles adhered to by Ukraine, our country decided to have resort to the instrument of soft power - public diplomacy. Ukraine developed a conceptual and institutional framework of public diplomacy and took a bunch of practical activities to improve its perception in the Western world. Though some advancements in presentation of Ukraine have been made, the efficiency of public diplomacy in the part of improving Ukraine's perception and in the part of countering Russian propaganda seems to be not high according to the assessment by Ukrainian and international experts. Therefore, some major steps based on the recommendations from experts should be taken into account. These include developing public diplomacy strategy (with two separate directions - West and Russia), stepping aside from Ukrainian centric approach to world oriented one, intensifying media coverage of Ukraine, shifting narratives about Ukraine (depends on success in reforming internally) and engaging subjects with credibility (such as civil activists and artists). 


\section{References}

1. Доктрина інформаційної безпеки України. Указ Президента України від 25 лютого 2017 p. [Decree of the President of Ukraine 'Doctrine of Information Security of Ukraine', 25 February 2017], <http://www.president.gov.ua/documents/472017-21374>

2. Концепція популяризації України у світі та просування інтересів України у світовому інформаційному просторі. Розпорядження Кабінету Міністрів України від 11 жовтня 2016 p. [Order of the Cabinet of Ministers of Ukraine 'The concept of Ukraine's popularization in the world and promotion of Ukraine's interests in the global information space', 11 October 2016], <https://zakon.rada.gov.ua/laws/show/739-2016-\%D1\%80>

3. План заходів з реалізації Концепції популяризації України у світі та просування інтересів України у світовому інформаційному просторі. Розпорядження Кабінету Міністрів України від 7 червня 2017 р. [Order of the Cabinet of Ministers of Ukraine 'Plan of Action on implementation of the concept of Ukraine's popularization in the world and promotion of Ukraine's interests in the global information space', 7 June 2017], $<$ https://zakon.rada.gov.ua/laws/show/383-2017-\%D1\%80>

4. Strategic Communication Joint Integrating Concept (2009). Department of Defence concept. Version 1.0, $<$ http://www.jcs.mil/Portals/36/Documents/Doctrine/concepts/jic_strategiccommunications.p df? ver $=2017-12-28-162005-353>$

5. Cull N. (2006) Public diplomacy before Gullion. The evolution of a phrase. USC Center on Public Diplomacy, <https://uscpublicdiplomacy.org/blog/public-diplomacygullion-evolution-phrase>

6. Ellul J. (1973) Propaganda. The formation of men's attitudes. New York: Taylor \& Francis.

7. McLuhan M., Lapham L. H. (1994) Understanding Media: The Extensions of Man. MIT Press.

8. Nye J. S. (2008) Public Diplomacy and Soft Power, The Annals of the American Academy of Political and Social Science 616 (1): 94-109

9. Nye J., Owen W. (1996) America's Information Edge. Foreign Affairs, $<$ https://www.foreignaffairs.com/articles/united-states/1996-03-01/americas-informationedge>

10. Ross C. (2003) Pillars of public diplomacy. Grappling with international public opinion. Harvard International Review 25(2): 22-28

11. Zaharna R.S. (2010) Battles to Bridges. U.S Strategic Communication and Public Diplomacy after 9/11. Palgrave Macmillan.

12. Біденко A. (2018) Єдиний бренд України [The only brand of Ukraine]. Українська правда, <https://blogs.pravda.com.ua/authors/bidenko/5af4228d75eea/>

13. Вишницька A. (2018) Володимир Шейко: «Неможливо творити культурні феномени, не зважаючи на те, що відбувається у світі» [Volodymyr Sheyko: 'It is impossible to create cultural phenomena, regardless of what is happening in the world']. Культура $i$ креативність, <https://www.culturepartnership.eu/ua/article/volodymyrsheiko>

14. Довбенко M. (2018) Чи змінився Kiev на Kуіv? Результати кампанії, спрямованої на міжнародні медіа [Has Kiev changed to Kyiv? Results of a campaign targeting international Padio Cвобода, $<$ https://www.radiosvoboda.org/a/29557242.html?fbclid=IwAR3OSCGmwlJ0Dg9HFLc32WGdFoScOuccTLBNqyujJGVS35KWZ25YzCJGwo>

15. Зернечька О. (1999) Глобальний розвиток систем масової комунікації $i$ міжнародні відносини [Global development of mass communication systems and international relations]. К. : Освіта. 
16. Кондратенко О. (2017) Геостратегічний вимір зовнішньої політики Російської Федерації [Geostrategic dimension of the foreign policy of the Russian Federation]. К. : ВПЦ «Київський університет».

17. Кулеба Д. (2015) Публічна дипломатія - нова зброя України в умовах гібридної війни. [Public diplomacy is a new weapon of Ukraine in a hybrid war.] Українська правда, <https://www.eurointegration.com.ua/experts/2015/09/23/7038633/>

18. Кучмій О. (2016) Культурна дипломатія [Cultural diplomacy]. Комунікативні тренди міжнародних відносин [Communication trends of international relations]. К. : Центр вільної преси.

19. Макаренко Є. (2016) Комунікативний інструментарій зовнішньої політики [Communication tools of foreign policy]. Комунікативні тренди міжнародних відносин [Communication trends of international relations]. К. : Центр вільної преси.

20. Тихомирова Є. (2004) Паблік рилейшнз у глобалізованому світі [Public relations in the global world]. К. : Наша культура і наука.

21. Хижняк I. (2018) Від 'навіки разом' до 'отпеs et singulos' (разом і окремо). Україна у системному протистоянні глобальних полюсів сили [From 'forever together' to 'omnes et singulos' (together and separately). Ukraine in the systemic confrontation of the global forces]. К. : Саміт-Книга.

22. Результати соціологічного опитування (2017): Якою побачили Украӥну гості Євробачення 2017? [How did Eurovision guests see Ukraine in 2017?] Інститут світової політики, <https://glavcom.ua/pub/pdf/49/4935/eurovision_2017_poll_ukr_0128.pdf>

23. Рік Української мови 2017/2018 [Year of the Ukrainian Language 2017/2018]. Посольство України в Німеччині. <https://germany.mfa.gov.ua/ua/ukraine-de/langyear>

24. Сайт myukraineis.org розкаже світові про Україну (2015) [The site myukraineis.org tells the world about Ukraine]. MЗС Украӥни, <https://mfa.gov.ua/ua/presscenter/news/42892-sajt-myukraineisorg-rozkazhe-svitovi-pro-ukrajinu>

25. Спеціальний звіт (2015) 'Основи організащії та приниипи діяльності державного іноземного телебачення $i$ радіомовлення Украӥни' [Special Report 'Fundamentals of Organization and Activities' Principles of the State Foreign Television and Radio Broadcasting Service of Ukraine']. ГО «Телекритика», $<$ https://ms.detector.media/content/files/telekritika_inomovlennja_2015.pdf $>$

УДК $327(71+73)$ 